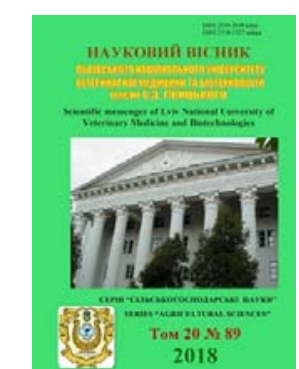

Науковий вісник Дьвівського національного університету ветеринарної медицини та біотехнологій імені С.3. Гжицького

\author{
Scientific Messenger of Lviv National University \\ of Veterinary Medicine and Biotechnologies
}

ISSN 2519-2698 print

doi: $10.32718 /$ nvlvet8920

ISSN 2518-1327 online

UDC 612.6. 636.082.4:591.31

\title{
Subsidiary methods of pregnancy diagnosis in diary cattle - alternative for the future
}

\author{
M. Sharan ${ }^{1}$, S. Shalovylo ${ }^{2}$ \\ ${ }^{1}$ Institute of animal biology NAAS, Lviv, Ukraine \\ ${ }^{2}$ Stepan Gzhytskyi National University of Veterinary Medicine and Biotechnologies Lviv, Ukraine
}

Article info

Received 21.09.2018

Received in revised form 24.10 .2018

Accepted 25.10.2018

Institute of Animal Biology of NAAS, V. Stusa Str., 38, Lviv, 79000, Ukraine.

E-mail:msharan@ukr.net

Stepan Gzhytskyi National University of Veterinary Medicine and Biotechnologies Lviv, Pekarska Str., 50, Lviv, 79010, Ukraine. Tel.: +38-097-383-45-17 E-mail: s.shalovulo@gmail.com
Sharan, M., \& Shalovylo, S. (2018). Subsidiary methods of pregnancy diagnosis in diary cattle alternative for the future. Scientific Messenger of Lviv National University of Veterinary Medicine and Biotechnologies, 20(89), 108-113. doi: 10.32718/nvlvet8920

Early pregnancy diagnosis in cows is one of the key elements of effective reproduction management of this species. Still imperfect effectiveness of procedures performed motivates veterinarians for further exploration of new techniques for the diagnosis of pregnancy and their new application. The following article aims to give existing laboratory methods and possibilities for their use in the diagnosis of pregnancy before the $3 r d$ day of insemination. In particular, substances that can be identified as soon as possible after insemination are presented: early pregnancy factor $(E P F)$, progesterone (P4), estrogen sulfate and pregnancy-associated glycoproteins (PAG). A detailed description of these substances and their role in the formation and maintenance of celibacy in cows are given. The possibility of using laboratory methods in modern milk reproduction protocols is shown. From the perspective of modern literature sources, the most effective laboratory methods for diagnosing pregnancy in dairy farming today are the definition of an early pregnancy factor (EPF) and pregnancy-associated glycoproteins $(P A G)$. Description of the methods available on the market and a new compilation (protocols) above techniques may be of interest for veterinarian involved in cattle reproduction. Despite the rapid development and the presence of more and more effective ultrasound devices, a practical veterinarian should not forget about the existence of indirect methods of diagnosis of pregnancy, which in large herds can significantly improve the economic conditions for the management of reproduction of cows in the future.

Key words: early pregnancy diagnosis, cattle, early pregnancy factor (EPF), pregnancy-associated glycoproteins (PAG), progesterone.

\section{Допоміжні методи діагностики тільності у корів молочних порід - альтернатива майбутньому}

\author{
М.М. Шаран ${ }^{1}$, С.Г. Шаловило ${ }^{2}$ \\ ${ }^{1}$ Інститут біології тварин НААН, м. Львів, Украӥна \\ ${ }^{2}$ Львівський національний університет ветеринарної медицини та біотехнологій імені С.3. Гжицького, \\ м Львів, Украӥна
}

Рання діагностика тільності у корів є одним з ключових елементів ефективного управління відтворенням тварин изого виду. Все ще недосконала ефективність проведених процедур мотивує ветеринарних лікарів продовжувати пошук нових методів діагностики тільності, а також їх нового використання. У статті описані сучасні лабораторні методи та можливості їх використання в діагностиці тільності корів вже через 3 дні після осіменіння. Зокрема, йде мова про речовини, які можна визначити якомога швидше після осіменіння: ранній фактор вагітності (early pregnancy factor, ЕРF), прогестерон (P4), сульфат естрону та глікопротеїни вагітності (pregnancy-associated glycoproteins, PAG). Наведено детальну характеристику вказаних речовин і їх роль у формуванні та підтриманні тільності у корів. Показано можливість використання лабораторних методів у сучасних протоколах відтворення молочної худоби. 3 огляду сучасних джерел літератури випливає, щсо найефективнішими лабораторними методами діагностики тільності в молочному скотарстві сьогодні є визначення раннього фактора вагітності (ЕРF) $і$ глікопротеӥнів вагітності (PAG). Опис методів, доступних сьогодні на ринку, та нових протоколів вищезгаданих методів може бути иікавим для кожного лікаря ветеринарної медицини. 
Ключові слова: рання діагностика тільності, велика рогата худоба, ранній фактор вагітності, глікопротеӥни вагітності, прогестерон.

\section{Вступ}

Інтенсифікація розведення великої рогатої худоби, зокрема молочних порід, останнім часом суттєво вплинула на розвиток прямих і непрямих методів ранньої діагностики тільності у корів. У великих стадах виникає необхідність проведення обстеження корів на тільність якомога раніше. У такий спосіб власники намагаються якнайшвидше ізолювати нетільних корів після осіменіння, щоб лікувати їх, синхронізувати статеву охоту й отримати запліднення i таким чином, скоротити міжотельний період. Метою акушерського обстеження є “виключення тільності” (а не іiі підтвердження), тому пошук в основному стосується методів, які характеризуються не тільки високою чутливістю, але й специфічністю (мінімізація помилкових результатів). Така поведінка головним чином пов'язана 3 іншою проблемою, $з$ якою стикаються ветеринарні лікарі, а саме пізня ембріональна смертність (18-42 дні після осіменіння).

В останні десять років найважливішим акушерським обстеженням, крім ректального дослідження, $\epsilon$ ультразвукове обстеження. Це дозволяє проводити діагностику тільності вже через 25-30 днів після осіменіння (Fricke, 2002), а ректальне дослідження найчастіше проводять близько 35-го дня (рекомендовано через 30 днів) (Youngquist, 1997). Обидва методи вимагають великого досвіду ветеринарного лікаря, а ультразвукове дослідження додатково потребує відповідного обладнання. Дослідження, що проводять у великих стадах, також вимагають багато фізичних зусиль, крім того, є певні обмеження щодо кількості обстежених тварин. У деяких країнах (наприклад в Австраліі), в яких невелика кількість ветеринарних лікарів залучена до акушерських досліджень корів, змушені приймати інші рішення. Всі ці чинники спричиняють нові обставини для використання лабораторних методів, які могли б полегшити роботу ветеринарного лікаря. Доказом цього є значне збільшення використання комерційних досліджень на наявність PAG (pregnancy-associated glycoproteins, глікопротеїнів вагітності) в крові осімінених корів, що 3 2005 до 2007 рр. зросло у 4 рази (з 80000 до 350000 тестів на рік, http://www.biotracking.com).

\section{Доступні лабораторні методи}

У діагностиці вагітності допоміжними методами використовуються тести для вимірювання молекул, котрі тісно співвідносяться 3 періодом вагітності, або ті, чия секреція в цей час істотно відрізняється від концентрації, зафіксованої у невагітних тварин. Матеріалом для тестування може бути кров або молоко. Оскільки у молочному скотарстві дуже важливим аспектом $є$ відсутність стресу в методах відбору зразків, багато нових досліджень стосуються молока, а також розробляються тести 3 використанням сечі тільних корів (Fricke et al., 2005).

У цьому огляді йдеться про речовини, які можна визначити якомога швидше після осіменіння. Це: ранній фактор вагітності (early pregnancy factor, EPF), прогестерон (Р4), сульфат естрону та глікопротеїни вагітності (pregnancy-associated glycoproteins, PAG).

Ранній фактор вагітності (Early Pregnancy Factor, EPF) або ранній фактор зачаття (Early Conception Factor ECF)

Ранній фактор вагітності - це протеїн, поява якого в організмі самки тісно корелює 3 вагітністю. Білки EPF належать до сімейства протеїнів теплового шоку та були вперше виділені у вагітних мишей за допомогою тесту інгібування розеток (Morton et al., 1987). Невдовзі білок ЕРF був ідентифікований в інших продуктивних ссавців, зокрема в овець та великої рогатої худоби. У подальших дослідженнях було встановлено, що білок ЕРF виділяється протягом 624 годин після запліднення і залишається на вимірюваному рівні до 24-48 годин після видалення/смерті ембріона/плоду (Morton et al., 1987). Вважається, що синтез білка ЕРF починається на ранній стадії вагітності, оскільки виконує імуносупресивну роль на організм самки, що дозволяє підтримувати вагітність та подальший розвиток ембріона. Про це свідчать дослідження 3 імунізованих антигенами анти-ERF вагітних мишей, у яких встановлено зупинку розвитку на стадії морули та ранньої бластоцисти у великої кількості тварин, які отримували імуноглобулін у перші дні вагітності (Athanasas et al., 1996). Окрім імуносупресивної функції, білок ЕРF також відіграє роль модулятора проліферації як звичайних, так i ракових клітин (Cavanagh, 1996).

Для діагностики тільності корів тест затримки розеткоутворення був ідентифікований як точний через 13-15 та 25 днів після запліднення (Sakonju et al., 1993), тимчасом як за використання антитіл анти-ЕРF ці білки можна виявити вже через 24-48 годин після осіменіння (Threlfall, 1994). Наступним було створення комерційного тесту (Concepto Diagnostics, Knoxville, TN), який сьогодні використовується в США. Чому цей метод діагностики ранньої тільності не набув поширення? Безсумнівно, було б важливим впровадження тестів виявлення тільності раніше, ніж 3 18-го дня після осіменіння через високу втрату ембріонів, викликану раннім періодом ембріональної смертності (EEM early embryonic mortality, втрати понад 40\% тільності). Сдина причина для проведення дослідження настільки рано - це підозра, що не було запліднення, яке вимагало б високої специфічності тесту. На жаль, метод виявлення білків ЕРF не відповідає такій умові. Дослідження про наявність фактору ранньої тільності в більшості виконаних експериментів був ускладнений дуже низькою специфічністю (Lopez-Gatius et al., 2007), і тому тест не дуже цікавий як ветеринарним лікарям, так і селекціонерам.

\section{Прогестерон (P4)}

Визначення концентрації прогестерону $є$ найпоширенішим методом лабораторної діагностики тільності у корів. Це стероїдний гормон, який продуку- 
ється жовтим тілом під час лютеальної фази статевого циклу і під час тільності. Коли відбувається запліднення, синтезований ембріоном інтерферон-таu пригнічує секрецію простагландину $\mathrm{F}_{2 \mathrm{a}}$ опосередковано (шляхом інгібування експресії рецепторів окситоцину в ендометріi), тим самим блокуючи лізис жовтого тіла (Wolf et al., 2003). Під час нормального статевого циклу періодично спостерігається зміна секреції P4, i під час тільності вона перебуває на постійному рівні протягом всієї тільності до родів. Концентрація прогестерону у тільних корів фіксується на рівні, наближеному до концентрації, що спостерігається у нетільних корів у лютеїновій фазі (> 7 нг/мл у молоці). Значна різниця в концентрації Р4 спостерігається між тільними та нетільними коровами під час фолікулярної фази, що і застосовується для діагностики тільності (для молока: тільні корів > 10 нг/мл, нетільні $<7$ нг/мл, 7-10 нг/мл - невизначений результат). Рекомендована дата тесту - період від 18-го до 24-го дня після осіменіння. У цей період більшість досліджуваних тварин, у яких не пройшло запліднення або ембріони загинули незабаром після запліднення, показали низький рівень прогестерону, що свідчить про перебіг нормального статевого циклу або відсутність тільності на момент дослідження.

Для визначення рівня прогестерону в молоці або в крові використовується метод радіоімунологічного аналізу (RIA) або ELISA. Комерційні тести, які можна проводити на місці відбору зразків, дають можливість визначити Р4 в молоці, що значно спрощує процедуру i скорочує час очікування на результат (кілька хвилин). На ринку такі тести доступні, і їх специфічність оцінюється в 98\% (Nebel et al., 1987). Незважаючи на наявність тестів, вони не знайшли широкого використання у відтворенні великої рогатої худоби. Причиною $є$ вартість одного тесту, необхідність повторення тесту з сумнівними результатами, а також патологічні зміни в статевих органах, що роблять результати тесту хибними. Під час звичайної діагностики деякі дослідники рекомендують проводити потрійний тест (у день осіменіння, через 18 та 24 днів), що дозволить знизити відсоток помилкових результатів у випадку тварин 3 подовженим циклом. Інша ситуація - при наявності патологічних явищ на яєчниках, таких як лютеїнові кісти, що зберігають секрецію Р4 довше, ніж фізіологічна фаза жовтого тіла. Всі ці чинники були підтверджені в останні роки, необхідність і вартість проведення прогестеронових тестів суттєво обмежила їх застосування на практиці, наприклад < 6\% стад у Польщі.

\section{Сульфат естрону}

Сульфат естрону - це стероїдний гормон, який спочатку застосовували для підтвердження тільності у корів, використовуючи молоко як тестовий матеріал (Hеap and Hamon, 1979). На відміну від прогестерону, концентрація якого не пов'язана безпосередньо 3 тільністю, сульфат естрону виробляється тільки під час тільності, тому його наявність є прямим ії підтвердженням. Концентрація сульфату естрону в молоці приблизно така ж, як і в плазмі крові. Від 60-го дня тільності спостерігається збільшення концентрації цього гормону до кінця лактації з виразною стадією плато, досягнутого приблизно на 150 дні тільності (Heap and Hamon, 1979). Проте визначення концентрації сульфату естрону в крові корів не $є$ надійним, оскільки перші вимірювання вмісту гормону можна проводити приблизно з 80 дня тільності та він присутній не у всіх корів до 100-го дня тільності. У зв'язку 3 цим сульфат естрону не становить більше інтересу як маркер тільності у великої рогатої худоби, ніж Р4 (Hamon et al., 1981).

Глікопротеїни вагітності (pregnancy-associated glycoproteins, PAG)

PAG - це велика родина глікопротеїнів, виділених у багатьох свійських (коні, свині, вівці тощо) та диких видів тварин (зубр, лама, зебра та ін.) (Sousa et al., 2006). Донині виявлено 21 білок bPAG (bovine Pregnancy-Associated Glycoproteins) (глікопротеїни тільності корів), які відрізняються між собою як біологічною активністю, так і періодом появлення в крові тільних корів. Родина глікопротеїнів класифікується біохімічно як група протеолітичних ферментів аспарагінових протеїназ (АР), однак у більшості не підтверджено ферментативної активності.

PAG - це молекули, синтезовані в клітинах зовнішнього шару трофобластів вже через кілька днів після запліднення. Гігантські клітини (MGC), утворені внаслідок злиття одно- і двоядерних клітин трофоектодерми з клітинами ендометрію, вивільняють накопичену зернистість через базальну мембрану в кровоносні судини матки і плаценти. Після імплантації ембріона в стінку матки глікопротеїни вагітності можна визначити в плазмі крові та молоці (рис. 1).

Враховуючи індивідуальні відмінності, було встановлено, що у більшості корів наявність PAG в крові спостерігається з 21-28 днів тільності протягом всієї їі тривалості до 80-100 днів після отелення (Gajewski et al., 2008; Gajewski et al., 2009). Підтвердження наявності PAG в молоці є можливим у більшості визначень 3 24-го дня тільності і може зберігатися до 60 дня після отелення (Roberts et al., 2015). Також активно проводяться експерименти з визначення PAG у молоці.

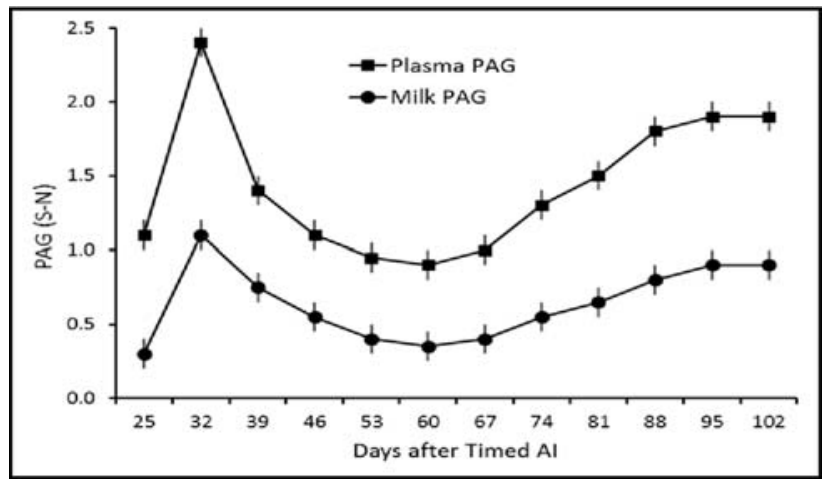

Рис. 1. Концентрація PAG у плазмі крові та молоці молочних корів у перші 100 днів після осіменіння (Fricke et al., 2005)

Визнаними методами вимірювання концентрації PAG в крові тільних корів $є$ RIA метод та імуноферментний метод ELISA. Чутливість і специфічність методу RIA описані як дуже високі і становлять від- 
повідно 92,0 та 82,6\% на 28-й день та 97 і 95\% - після 35-го дня після осіменіння (Szenci et al., 1998). Зараз на ринку існують тести для швидкої діагностики PAG у крові (зокрема, Bioprine: BioTracking, LLC, Москва, $\mathrm{LD}, \mathrm{CШA).} \mathrm{Цей} \mathrm{метод} \mathrm{діагностики} \mathrm{ранньої} \mathrm{тільності} \epsilon$ точним для всіх осімінених тварин, за винятком тих, у яких міжотельний період менше ніж 65 днів. У тварин, досліджених до 30-го дня після осіменіння, тест може виявити молекули PAG з попередньої тільності, тому рекомендується повторити тестування на 60-й день очікуваної тільності (http://www.biotracking.com). За даними досліджень J.A. Green i співавт. (Green et al., 2005), після 27-го дня після осіменіння дослідження концентрації PAG у сироватці крові та ректальне ультразвукове дослідження характеризуються високим рівнем кореляції ( $\mathrm{r}=0,87-0,90)$, що дозволяє порівнювати їх діагностичне значення протягом цього періоду тільності. В іншому дослідженні М. Pechotta i співавт. (Piechotta et al., 2011) порівнювали два аналізи ELISA (тест BioPYN та IDEXX Bovine Pregna рис. 2). У дослідній групі на 197 тільних коровах 319 ферм чутливість та специфічність обох методів була приблизно на одному рівні $(98,0$ та 97,1\% відповідно для BioPRYN та 97,8 та 91,2\% для IDEXX Bovine Pregnancy Test), що підтверджують обгрунтованість їх використання в клінічній практиці. 3 розвитком тільності збільшується плацента, рівень PAG зростає і дозволяє підтвердити тільність у будь-який момент від іiі початку до родів.
Діагностика тільності за допомогою тестів PAG у випадку ранньої (EEM early embryonic mortality) та пізньої ембріональної смертності (LEM late embryonic mortallty), поєднана 3 акушерським обстеженням, може сприяти швидшій діагностиці аборту. У випадку EЕM концентрація PAG зазвичай істотно не відрізняється від концентрації у нетільних корів, хоча існує ризик помилкових результатів. Інакше виглядає ситуація у випадку LEM. 3 наявної літератури випливає, що рівень PAG залежно від типу порушень може збільшуватися або зменшуватися перед настанням аборту. Оскільки період піврозпаду PAG-1 (глікопротеїн ВРХ) коливається від 3 до 7 днів, реакція у вигляді зниження рівня PAG у крові затримується (Whitlock and Maxwell, 2008).

Через індивідуальні відмінності рівня PAG в крові тільних корів лише чітке зменшення концентрації (необхідність проведення двох тестів) або відсутність часток у досліджуваній крові може підтвердити загибель ембріона або плоду. Отже, період відразу після аборту носить ризик помилкових результатів. Однак це не завжди так. Концентрація глікопротеїнів тільності насамперед залежить від секреторної функції плаценти, тому у випадку патологій тільності, що впливають на функціонування трофобластів, рівень PAG може бути доказом змін у присутності ще живого плоду. Так відбувається у випадку абортів, викликаних інфікуванням Neospora caninum.

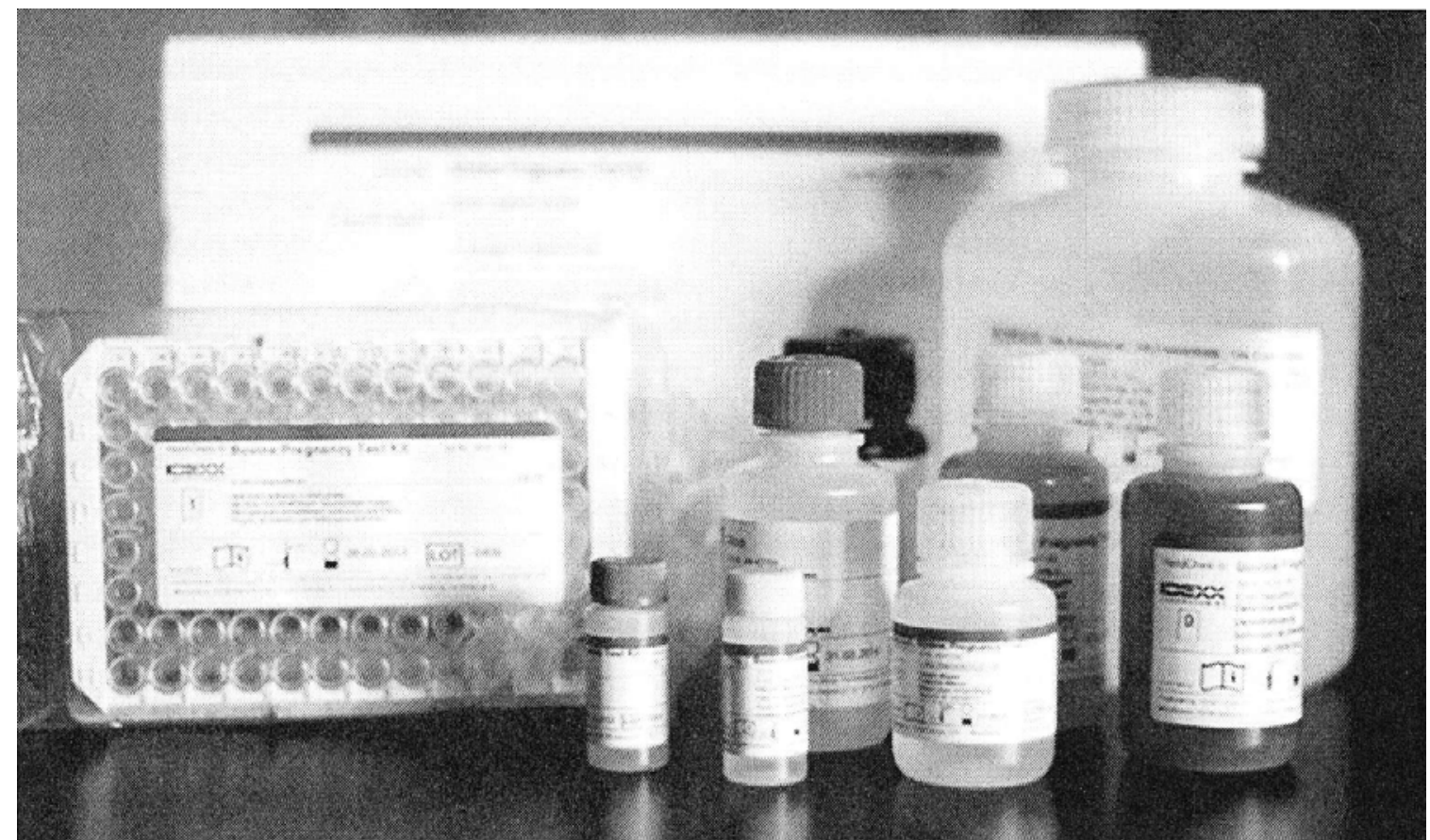

Рис. 2. Тест ELISA для визначення концентрації PAG у плазмі крові: IDEXX Bovine Pregnancy Test Kit

У дослідженнях F. Lopez-Gatius та співавт. (LopezGatius et al., 2007) було зазначено, що концентрація PAG у крові тільних корів, в якій виявлені антитіла проти антигенів Neospora caninum, не змінюється щодо серонегативних тварин. Однак такі зміни були відзначені у корів, у яких пізніше наступали аборти. Виявлено негативну кореляцію між концентрацією
PAG-2 у плазмі корів на 120-й день тільності та ризиком аборту. У серопозитивних тварин з високим рівнем PAG-2 (> 4,5 нг/мл) на 120-й день тільності ризик аборту був у 0,24 разу нижчим, ніж у корів 3 меншою концентрацією. У зв'язку з вищесказаним було встановлено, що концентрація PAG-2 у плазмі крові на 120-й день може слугувати показником ризику втрати 
тільності на фоні інфекції N.caninum (Garcia-lspierto et al., 2013).

Протилежна ситуація спостерігається при зараженні тільних корів бактеріями Coxiella burnetti. На 120-й день тільності у корів з високим рівнем антитіл проти C. burnetti спостерігали підвищений рівень PAG в плазмі крові порівняно 3 коровами 3 нижчим рівнем антитіл або серонегативних (Garcia-lspierto et al., 2013). У другій половині тільності спостерігалося значне зниження концентрації PAG порівняно з неінфікованими коровами. Крім того, у цьому ж дослідженні було зазначено, що в корів, інфікованих C. burnetti, встановлено найнижчі значення прогестерону в плазмі крові на 120-й день, порівняно $з$ іншими досліджуваними тваринами. Цей феномен співіснування високої концентрації PAG і низького рівня Р4, ймовірно, відображає регуляторний механізм плоду. Автор вказує на посилення секреторної функції плаценти для підтримки тільності при низькому рівні прогестерону в плазмі. Ця ідея підтверджується тим фактом, що корови 3 високим титром антитіл до C. burnetti i високим рівнем кортизолу у плазмі крові характеризувалися зниженням продукції PAG від 150го дня до закінчення тільності. Зниження секреції PAG автор пояснює негативним впливом кортизолу на плаценту та плід.

Застосування окремих непрямих методів у нових протоколах відтворення молочної худоби

Варто зазначити, що використання непрямих діагностичних методів у корів набуває популярності серед ветеринарних лікарів, які займаються розмноженням великих стад. Розробляються нові протоколи синхронізації статевої охоти та скорочення міжотельного періоду в молочних корів за допомогою лабораторних тестів. Прикладом може бути розроблена програма, яка поєднує синхронізацію статевої охоти за допомогою програми CIDR-Ovsynch та тестів, що виявляють білок PAG (Green et al., 2011). У згаданій роботі порівнювалися дві програми, де в першій для діагностики тільності були використані тести PAG, у другій - ультразвукове обстеження. У тварини обох груп синхронізацію охоти проводили за допомогою вагінальних вкладок з прогестероном (CIDR) через 18 днів після осіменіння. У корів першої групи вагінальні вкладки були вилучені на 25-й день і досліджено тварин за допомогою тестів ELISA на наявність PAG. Нетільним коровам у цей же день вводили простагландин (PG) $\mathrm{F}_{2 \mathrm{a}}$, а через два дні - гонадотропін-рилізінг гормон (GnRH; 27-й день) і осіменяли на 28-й день. Тваринам другої групи виймали вагінальні вкладки CIDR на 32-й день і проводили ультразвукову діагностику тільності. Нетільним коровам, подібно до першої групи, вводили $\mathrm{PGF}_{2 \mathrm{a}}$, а через два дні (на 34-й день) GnRH і осіменяли на 35-й день після попереднього осіменіння. В обох групах (1: n=103, II: n =99) був отриманий аналогічний відсоток отелень, тому ефективність обох процедур майже однакова. Скорочення процесу синхронізації охоти з 35 до 28 днів за допомогою методів, які не потребують виявлення статевої охоти, є доброю перспективою у відтворенні молочної худоби.

\section{Висновки}

Незважаючи на стрімкий розвиток та наявність щораз ефективніших ультразвукових пристроїв, практичний ветеринарний лікар не повинен забувати про існування непрямих методів діагностики вагітності, що у великих стадах можуть в майбутньому істотно поліпшити економічні умови управління розмноженням корів.

\section{References}

Athanasas, S., Mofton, H., Dunglison, G.F., \& Kaye, P.L. (1996). Antibodies to early pregnancy factor retard embryonic development in mice in vivo. J. Reprod. Fert., 92(2), 443-454. https://www.ncbi.nlm.nih.gov/ pubmed/1886100.

Cavanagh, A. (1996). Identification of early pregnancy factor as chaperonin 10: implications for understanding its role. Rev. Reprod., 1(1), 28-32. https://www.ncbi.nlm.nih.gov/pubmed/9414435.

Cordoba, M.C., Sartori, R., \& Fricke, P.M. (2001) Assessment of a commercially available Early Conception Factor (ECF) test for determining pregnancy status of dairy cattle. J. Dairy Sci., 84, 1884-1889. https://pdfs.semanticscholar.org/7ee5/4d9b12a06c5c6f 3bda3fd68339e880374c7c.pdf.

Fricke, P.M., Ricci, A., Carvalho, P., \& Amundson, M. (2005). Milk vs blood-which is best for PAG pregnancy prediction? Western Dairy Management Conference, Proceedings, Mar 3-5, Reno, NV. https://pdfs.semanticscholar.org/3793/61987e5f714f0a 08228fcdbce9b3189690f8.pdf.

Fricke, P.M. (2002). Scanning the future - Ultrasonography as a reproductive management tool for dairy cattle. J. Dairy Sci., 85(8), 1918-1926. doi: 10.3168/jds.S0022-0302(02)74268-9.

Gajewski, Z., Melo de Sousa, N., Beckers, J.F., Pawlinski, B., Olszewska, M., Thun, R., \& Kleczkowski, M. (2008). Concentration of bovine Pregnancy Associated Glycoprotein in plasma and milk: it's application for pregnancy diagnosis in cows. J. Physio. Pharm., 59(9), 55-64. https://www.ncbi.nlm.nih.gov/ pubmed/19261971.

Gajewski, Z., Pertajtis, M., Sousa, N.M., Beckers, J.F., Pawlinski, B., \& Janett, F. (2009). Pregnancyassociated glycoproteins as a new diagnostic tool in cattle reproduction. Schweizer Archiv fijr Tierheilkunde, (151)12, 577-582. doi: 10.1024/00367281.151.12.577.

Garcia-lspierto, I., Almeria, S., Serrano, B., de Sousa, N., Beckers, J., \& Lopez-Gatlus, F. (2013). Plasma Concentrations of Pregnancy-Associated Glycoproteins Measured Using Anti-Bovine PAG-2 Antibodies on Day 120 of Gestatron Predict Abortion in Dairy Cows Naturally lnfected with Neospora caninum. Reprod. in Domestic An., 48(4), 613-618. doi: 10.1111/rda.12134.

Green, J.C., Newsom, E.M., \& Lucy M.C. (2011) Incorporation of a rapid pregnancy-associated glycoprotein ELISA into a CIDR-Ovsynch resynchronization program for a 28 day re-insemination interval. Theriogenology, 75(2), 320-328. doi: 10.1016/j.theriogenology.2010.09.002. 
Green, J.A., Parks, T.E., Avalle, M.P, Telugu, B.P., McLain, A.I., \& Peterson, A.J. (2005). The establishment of an ELISA for the detection of pregnancyassociated glycoproteins (PAGs) in the serum of pregnant cows and heifers. Theriogenology, 63, 1481-503. doi: 10.1016/j.theriogenology.2004.07.011.

Hamon, M., Fleet, I.R., Holdsworlh, R.J., \& Heap, R.B. (1981). The lime of detection of oestrone sulphate in milk and the diagnosis of pregnancy in cows. British Vet. J., 137, 3-11.

Heap, R.B., \& Hamon, M. (1979). Oestrone sulphate in milk as an indicator of a viable conceptus in cows. Brit. Vet. J., 135(4), 355-363. https://www.ncbi. nlm.nih.gov/pubmed/534929.

Lopez-Gatius, F., Garbayo, J. M., Santolaria, P., Yaniz J.I., Almeria, S., Ayad, A., de Sousa, N.M., \& Beckers, J.F. (2007). Plasma pregnancy-associated glycoprotein-1 (PAG-1) concentrations during gestation in Neospora-infected dairy cows. Theriogenology, 67(3), 502-508. doi: 10.1016/j.theriogenology.2006.08.014.

Morton, H., Rolfe, B.E., \& Cavanagh, A.C. (1987). Ovum factor and early pregnancy factor. In Current Topics in Developmental Biology, 23, 73-92. https://www.ncbi. nlm.nih.gov/pubmed/3330508.

Nebel, R.I., Whittier, W.D., Cassell, B.G., \& Britt, J.H. (1987). Comparison of on-farm and laboratory milk progesterone assays for identifying errors in detection of estrus and diagnosis of pregnancy. J Dairy Sci., 70(7), 1471-1476. https://www.ncbi.nlm.nih.gov/ pubmed/3624599.

Piechotta, M., Bollwein, J., Friedrich, M., Heilkenbrinker, I. Passavant, C., Branen, J., Sasser, G., Hoedemaker, M., \& Bollwein, H. (2011). Comparison of commercial ELISA blood tests for early pregnancy detection in dairy cows. J. Reprod. Dev., 57(1), 72-75. https://www.ncbi.nlm.nih.gov/pubmed/20881353.
Roberts, J., Byrem, T., \& Grooms, D. (2015). Application of an ELISA Milk Pregnancy Test in Beef Cows. Reprod. in DomesticAnim, 50(4), 651-658. doi: 10.1111/rda.12546.

Sakonju, S., Enomoto, S., Kaminura, S., \& Amana, K. (1993). Monitoring bovine embryo viability with 698 early pregnancy factor. J Vet. Med. Sci., 55, 271-274.

Sousa, N.M., Ayad, A., Beckers, J.F., \& Gajewski Z. (2006). Pregnancy-associated glycoproteins (PAG) as pregnancy markers in the ruminants. J. Physiol. Pharmacol., 57 (8), 153-171. https://www.ncbi.nlm.nih.gov/ pubmed/17242480.

Szenci, O., Beckers, J.F., Humblot, P, Sulon, J., Sasser, G., Taverne, M.A.M., Varga, J., Baltusen, R., \& Schekk, G. (1998). Comparison of ultrasonography, bovine pregnancy-specific protein $\mathrm{B}$, and bovine pregnancyassociated glycoprotein 1 tests for pregnancy detection in dairy cows. Theriogenology, 50(1), 77-88. https://www.ncbi.nlm.nih.gov/pubmed/10734476.

Threlfall, W.R. (1994). Immunosuppressive early pregnancy factor (ISEPF) determination for pregnancy diagnosis in dairy cows. Theriogenology, 41, 317.

Whitlock, B.K., \& Maxwell, H.S. (2008). Pregnancyassociated glycoproteins and pregnancy wastage in cattle. Theriogenology, 70(3), 550-559. doi: 10.1016/j.theriogenology.2008.05.003.

Wolf, E., Arnold, G.J., Bauersachs, S., Beier, H.M., Blum, H., Einspanier, R., Frohlich, T., Herrler, A., Hiendleder, S., Kolle, S., Prelle, K., Reichenbach, H.D., Stojkovic, M., Wenrgerkind, H., \& Sinowatz, F. (2003). Embryo-maternal communication in bovine strategies for deciphering a complex cross-talk. Reprod. Dom. Anim., 38(4), 276-289. https://www.ncbi.nlm.nih.gov/pubmed/12887567.

Youngquist, R.S. (1997). Pregnancy diagnosis. Current Therapy in Large Animal Theriogenology, 1, 295303. 